\title{
One Pot Synthesis, Characterization of Benzothiazole/ Benzimidazole Tethered Imidazole derivatives Using Clay As Catalyst
}

\author{
HIMANSHU PANDEY^ and S. P. SHRIVASTAVA \\ Department of Chemistry, Dr. Harisingh Gour Vishwavidyalaya (Central) Sagar-470003, India. \\ ${ }^{*}$ Corresponding author E-mail: himpan5040@gmail.com \\ http://dx.doi.org/10.13005/ojc/370309
}

(Received: April 19, 2021; Accepted: June 05, 2021)

\begin{abstract}
A Green approach for benzothiazole/benzimidazole tethered imidazole derivative synthesis utilizing brick derived clay as a catalyst. Brick clay catalyst used in this synthesis has shown excellent catalytic activity by increasing efficiency, reducing the reaction time and most importantly it is reusable for further reaction runs. These derivatives were synthesized by four component condensation reaction that involve benzil, aldehyde, 2-aminobenzimidazole/2-amino-6-nitrobenzothiazole and ammonium acetate. The clay catalyst is characterized by FT-IR while the synthesized derivatives were characterized by FT-IR, ${ }^{1} \mathrm{H}$ NMR and ${ }^{13} \mathrm{C}$ NMR. Brick clay is a cheap, non-hazardous catalyst and can be reused up to many reaction runs with good to excellent yields.
\end{abstract}

Keywords: Imidazole, Benzothiazole, Benzimidazole, Clay catalyst, Green synthesis.

\section{INTRODUCTION}

The development of economical and environmentally viable catalyst has a great importance in the field of organic synthesis and is extensively needed for industrial processes. In recent years heterogeneous catalysts have attracted huge interest due to their magnificent properties in organic synthesis. Heterogeneous catalyst exhibits excellent catalytic activity with ability of easy separation from the synthesized product and reusability. Current reports on the heterogeneous catalysts have highlighted their tremendous arena of modifications and applications on the new fronts of organic synthesis. The magnetic nanophotocatalyst
$\mathrm{WO}_{3} \mathrm{ZnO} / \mathrm{Fe}_{3} \mathrm{O}_{4}$ developed for the synthesis of benzimidazole derivatives ${ }^{1}$. The nanocomposite $\mathrm{W}-\mathrm{ZnO} @ \mathrm{NH}_{2}-\mathrm{CBB}$ successfully used as a photocatalyst for the photochemical synthesis of benzimidazoles induced by UV-Visible light ${ }^{2}$. The magnetic catalyst $\mathrm{H}_{3} \mathrm{PW}_{12} \mathrm{O}_{40} @ \mathrm{Fe}_{3} \mathrm{O}_{4}$ /EN-MIL-101 used for synthesis of indazolo phthalazine-triones ${ }^{3}$. A nanoporous basic catalyst developed by grafting amine on UiO-66 and used for the synthesis of 2-Aminithiophenes ${ }^{4}$. The mesoporous catalyst $\mathrm{Nb}-\mathrm{Zr} / \mathrm{KIT}-6$ successfully used for benzylpyrazolyl coumarins synthesis ${ }^{5}$. The synthesis of 3-substituted indoles were reported by using $\mathrm{H}_{5} \mathrm{PW}_{10} \mathrm{~V}_{2} \mathrm{O}_{40} @ \mathrm{VO}_{\mathrm{x}} /$ SBA-15- $\mathrm{NH}_{2}$ as a catalyst ${ }^{6}$. Heterogeneous catalysts exhibit properties like low toxicity, recyclability, easy

This is an Open Access article licensed under a Creative Commons license: Attribution 4.0 International (CC- BY). Published by Oriental Scientific Publishing Company @ 2018 
separation, great diversity at structural level and stability at high temperatures ${ }^{7-10}$.

The clay material forms an important part of heterogeneous catalysts due their vast availability and interesting catalytic properties. In recent times, these are heavily explored for their catalytic potential in organic synthesis ${ }^{11}$. The naturally occurring clays are mostly acidic in nature and exhibit high surface area. The clay catalysts found their prominent applications in the field of refining of petroleum and transformation of bio-ethanol into hydrocarbons ${ }^{12,13}$. The need for cheap, non-toxic and reusable catalysts is very high in industrial processes. Red brick clay which is easily available and non-hazardous is a perfect catalytic material ${ }^{14,15}$. Red brick clay is composed of mainly $\mathrm{SiO}_{2}(12.36 \%), \mathrm{Fe}_{2} \mathrm{O}_{3}(5.28 \%)$ and $\mathrm{Al}_{2} \mathrm{O}_{3}(5.23 \%)$. The red brick clay has been used as an efficient catalyst in many reactions and it also showed selective 1,4-butanediol dehydration with an excellent yield ${ }^{16,17}$. The photo-catalytic oxidative degradation of dyes like malachite green (MG) is efficiently catalyzed by iron and zinc supported on red brick nanocomposites ${ }^{18,19}$.

Nitrogen containing heterocyclic moieties has a huge importance in organic synthesis ${ }^{20}$. Imidazole moiety has significance in synthetic and medicinal fields due to its crucial role as building blocks in products of natural origin ${ }^{21}$. Imidazole derivatives attracted significant attention by their prominent biological activities that include antihypertensive, antimicrobial and anticancer ${ }^{22-25}$. Benzimidazole is a crucial moiety in the field of medicinal chemistry owing to a wide variety of pharmacological and biological activities, which include anticancer, antimicrobial and antiinflammatory ${ }^{26-29}$. Benzothiazole is another prominent moiety which possesses a broad range of biological activities. The benzothiazole derivatives incorporating imidazole moiety exhibited tremendous antifungal activity. Benzothiazole derivatives were also known for their anticancer activity. The magnificent activities of these moieties inspired us to synthesize the imidazole derivatives with benzimidazole and benzothiazole. The benzimidazole/benzothiazole tethered imidazole derivatives definitely provide leads for further drug development. ${ }^{30,31}$

Over the years, researchers have introduced wide variety of catalyst for the synthesis of imidazole derivatives. Reports have revealed that zeolite $^{32}$, p-dodecylbenzenesulfonic acid (DBSA) ${ }^{33}$,

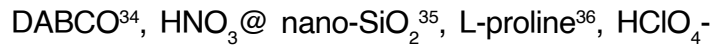
$\mathrm{SiO}_{4}{ }^{37}, \mathrm{PEG}-400^{38}, \mathrm{MgAl}_{2} \mathrm{O}_{4}{ }^{39}$, nano $\mathrm{TiCl}_{4}-\mathrm{SiO}_{2}{ }^{40}$, nano-crystalline sulfated zirconia ${ }^{41}, \mathrm{NH}_{4} \mathrm{Fe}\left(\mathrm{SO}_{4}\right)_{2} \mathrm{KOH}^{42}$, Phenoxyl Spacer ${ }^{43}$, nanocrystalline silica supported tin oxide $\left(\mathrm{SiO}_{2}: \mathrm{SnO}_{2}\right)^{44}$, Sodium lauryl sulfate ${ }^{45}, \mathrm{Cu} @$ imine $/ \mathrm{Fe}_{3} \mathrm{O}_{4}$ magnetic nanoparticles ${ }^{46}$, sulfamic acid functionalized hollow magnetic spheres ${ }^{47}$ have significantly improved the efficiency but environmental aspects remain overlooked. The novelty of this work lies in the fact that we have reported a greener catalyst in the form of brick derived clay which is very economical due to easy availability with simple workup and we have successfully utilized it for the synthesis of benzothiazole/ benzimidazole tethered imidazole derivatives with very good efficiency. The synthesized benzothiazole/ benzimidazole tethered imidazole derivatives can provide important leads for further drug development. Brick derived clay proved itself as a promising catalyst in this synthesis with additional benefits of its cheapness, easy availability with simple workup, reusability and most importantly it is environmentally favorable material as compared to other alternatives.

Herein, we report inexpensive, reusable and non-toxic brick derived catalyst for the synthesis of benzothiazole/benzimidazole tethered imidazole derivatives by one pot condensation reaction with terrific yields.

\section{MATERIAL AND METHODS}

The reagents used in this research work were obtained from Sigma Aldrich, Merck and Loba-chemie. The brick derived clay material used in this synthesis was obtained by grinding the red brick to fine powder. The reaction progress was monitored using TLC Silica gel 60 aluminum plates (Merck). Melting points of all the derivatives were observed in thermal apparatus for melting point. FT-IR spectra were recorded by using Bruker FT-IR spectrophotometer. JEOL JNM-ECX500 spectrometer was used for ${ }^{1} \mathrm{HNMR}$ and ${ }^{13} \mathrm{CNMR}$ analysis of derivatives.

\section{Synthesis of brick derived clay catalyst}

The clay material was obtained by grinding the brick to fine powder. This grinded powder is then heated in the oven for $24 \mathrm{~h}$ at $120^{\circ} \mathrm{C}$ to make it moisture free. 


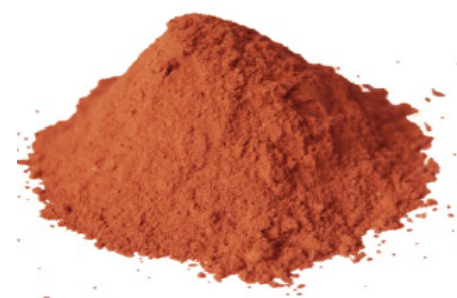

Brick derived clay

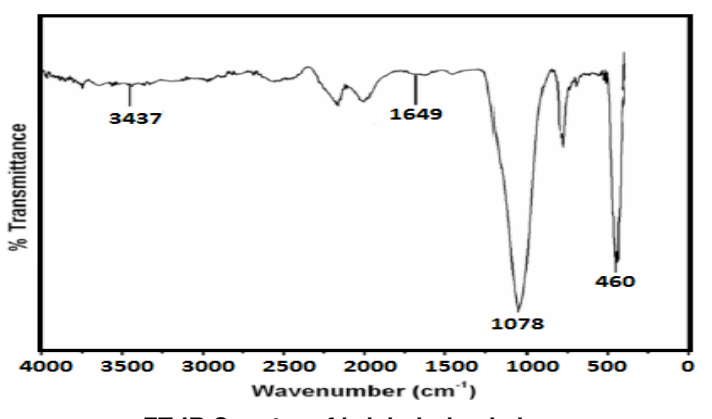

FT-IR Spectra of brick derived clay

Synthesis of benzothiazole/benzimidazole tethered imidazole derivatives

General procedure

All the four components namely benzil,2aminobenzimidazole/2-amino-6-nitrobenzothiazole, selected aldehyde, ammonium acetate were taken in one millimolar quantity along with brick derived clay catalyst $(50 \mathrm{mg})$ in ethanol and refluxed for $45-60 \mathrm{~min}$ at $70^{\circ} \mathrm{C}$. The progression of the reaction is observed by thin layer chromatography (Ethyl acetate-n-hexane 2:3). When the reaction reaches its completion the product filtered for separating the catalyst and cooled at room temperature. The recrystallization has done with ethanol and product obtained with optimum purity.

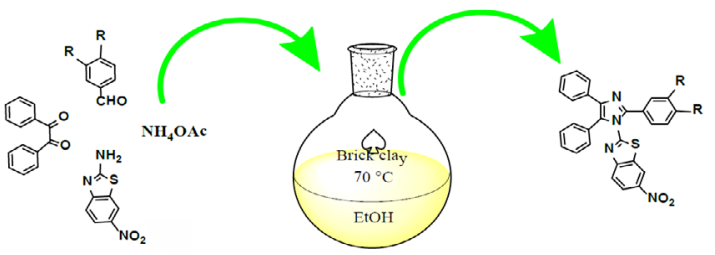

Reaction scheme for the synthesis of benzothiazole tethered imidazole derivatives

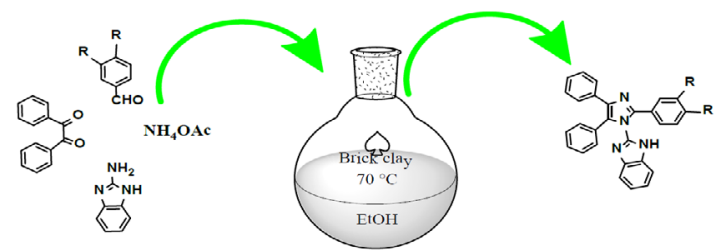

Reaction scheme for the synthesis of benzimidazole tethered imidazole derivatives
N,N-dimethyl-4-(1-(6-nitrobenzo[d]thiazol-2-yl)4,5-diphenyl-1H-imidazol-2-yl)aniline (HP-1) yellow solid; yield $89 \%$; m.p. $210-213^{\circ} \mathrm{C}$; $\mathrm{IR}\left(\cup \max , \mathrm{cm}^{-1}\right): 3025(=\mathrm{C}-\mathrm{H}), 1648(\mathrm{C}=\mathrm{C}$, imidazole), 1540( $\mathrm{C}=\mathrm{N}$, imidazole); ${ }^{1} \mathrm{H}$ NMR (400 $\left.\mathrm{MHz}, \mathrm{DMSO}-d_{6}\right)$ 8.01-8.67( $d$, 3H, Ar-H), 6.70-7.6 $(d, 4 \mathrm{H}, \mathrm{Ar}-\mathrm{H}), 7.27-7.40$ (d, 10H, Ar-H), 3.04 (s, 6H, C-H); ${ }^{13} \mathrm{C}$ NMR (100 MHz, DMSO- $\left.d_{6}\right)$ 172, 158, 157, $153,144,141,138,135,133,131.8,130,126,125$, $123,122,121,120,119,117,112,111,110,49,48$, 42, 40, 39, 38, 37 .

\section{2-(2-(3,4-dimethoxyphenyl)-4,5-diphenyl-1H- imidazol-1-yl)-6-nitrobenzo[d] thiazole (HP-2)}

Pale yellow solid; yield $86 \%$; m.p. 196$199^{\circ} \mathrm{C}$; IR(u max, $\left.\mathrm{cm}^{-1}\right): 3030(=\mathrm{C}-\mathrm{H}), 1674(\mathrm{C}=\mathrm{C}$, imidazole), 1583(C=N, imidazole); ${ }^{1} \mathrm{H}$ NMR (400 $\mathrm{MHz}$, DMSO- $d_{6}$ ) 8.01-8.06(d, 3H, benzothiazole), 7.5-7.9 (d, 10H, C-H), 7.01-7.04 (d, 3H, C-H), 3.8 $\left(d, 6 \mathrm{H}, \mathrm{O}-\mathrm{CH}_{3}\right) ;{ }^{13} \mathrm{C} \mathrm{NMR}\left(100 \mathrm{MHz}\right.$, DMSO- $\left.d_{6}\right) 196$, $192,172,171,156,149,142,138,137,136,135$, $132,131,130,129,128,127,125,123,115,112$, 109, 98, 95, 58, 56, 42, 40, 38.

4-(1-(1H-benzo[d]imidazol-2-yl)-4,5-diphenyl-1Himidazol-2-yl)-N,N-dimethylaniline (HP-3)

White solid; yield $88 \%$; m.p. $205-208^{\circ} \mathrm{C}$; IR(v $\left.\max , \mathrm{cm}^{-1}\right): 3248(\mathrm{NH}) 3015(=\mathrm{C}-\mathrm{H}), 1675(\mathrm{C}=\mathrm{C}$, imidazole), $1533\left(\mathrm{C}=\mathrm{N}\right.$, imidazole); ${ }^{1} \mathrm{H}$ NMR (400 $\mathrm{MHz}$, DMSO- $\left.d_{6}\right)$ 9.4-7.9(d, 4H, Ar-H), 6.7-7 (d, 4H, Ar-H, Benzimidazole), 7.6-7.9 (t, 10H, C-H), $6.02(d$, $1 \mathrm{H}, \mathrm{N}-\mathrm{H}), 3.04$ (s, $\left.6 \mathrm{H}, \mathrm{N}-\mathrm{CH}_{3}\right) ;{ }^{13} \mathrm{C} \mathrm{NMR}(100 \mathrm{MHz}$, DMSO- $\left.d_{6}\right)$ 196, 194, 193, 192, 190, 188, 185, 172, $170,156,154,146,139,137,133,132,131,130$, 128, 126, 125, 120, 112, 44, 42, 41, 40, 39, 38, 21.

2-(2-(3,4-dimethoxyphenyl)-4,5-diphenyl-1Himidazol-1-yl)-1H-benzo[d]imidazole (HP-4)

White solid; yield $84 \%$; m.p. $215-218^{\circ} \mathrm{C}$; $\mathrm{IR}\left(\cup \max , \mathrm{cm}^{-1}\right): 3090(=\mathrm{C}-\mathrm{H}), 1673(\mathrm{C}=\mathrm{C}$, imidazole), $1508\left(\mathrm{C}=\mathrm{N}\right.$, imidazole); ${ }^{1} \mathrm{H}$ NMR (400 $\mathrm{MHz}$, DMSO- $\left.d_{6}\right)$ 9.7-7.9 (d, 10H, Ar-H), 7.1-7.3 (d, 4H, Benzimidazole), 7.01-7.04 (d, 3H, C-H), 6.02 (d, $1 \mathrm{H}, \mathrm{N}-\mathrm{H}), 3.7\left(\mathrm{~d}, 6 \mathrm{H}, \mathrm{O}-\mathrm{CH}_{3}\right) ;{ }^{13} \mathrm{C}$ NMR $(100 \mathrm{MHz}$, DMSO-d $\left.d_{6}\right) 194,193,191,174,170,156,154,153$, $149,146,139,138,136,134,133,129,128,126$, 119, 118, 117, 113, 112, 110, 56, 54, 42, 40, 39, 22.

\section{RESULTS AND DISCUSSION}

In our investigation, the brick derived 
clay has emerged as a promising catalyst for the synthesis of benzothiazole/benzimidazole tethered imidazole derivatives. The work up is straight forward without any hectic procedure. All the four component reactions were carried out at $70^{\circ} \mathrm{C}$ and reached completion point within 45 to 60 min with very high efficiency. The yield of imidazole derivatives mainly depends on the functional group associated with aldehyde. An aldehyde with electron-withdrawing groups yields more in comparison to aldehyde with electron-donor groups. The FT-IR spectrum of the products showed characteristic vibrational bands of imidazole moiety at $1596 \mathrm{~cm}^{-1}$ for $\mathrm{C}=\mathrm{N}$ and 1675 $\mathrm{cm}^{-1}$ for $\mathrm{C}=\mathrm{C}$ groups.
The catalyst has exhibited excellent efficiency in all the reactions and the product yield of various derivatives of benzothiazole/benzimidazole tethered imidazole were $84-89 \%$ as shown in Table 1.

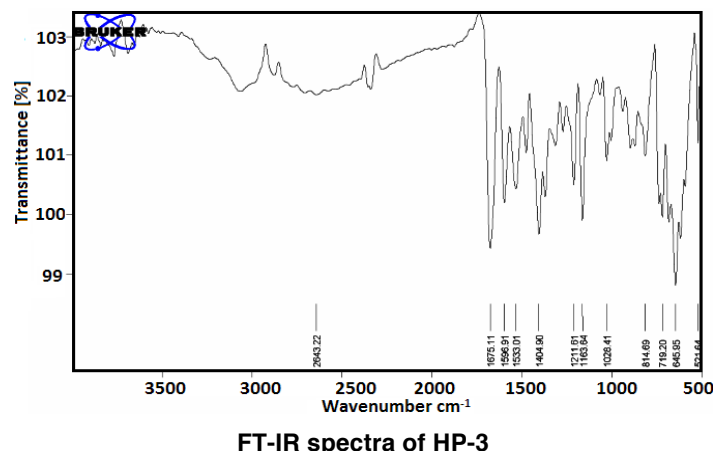

Table 1: Showing synthesized benzothiazole/benzimidazole tethered imidazole derivatives with reaction time and yield

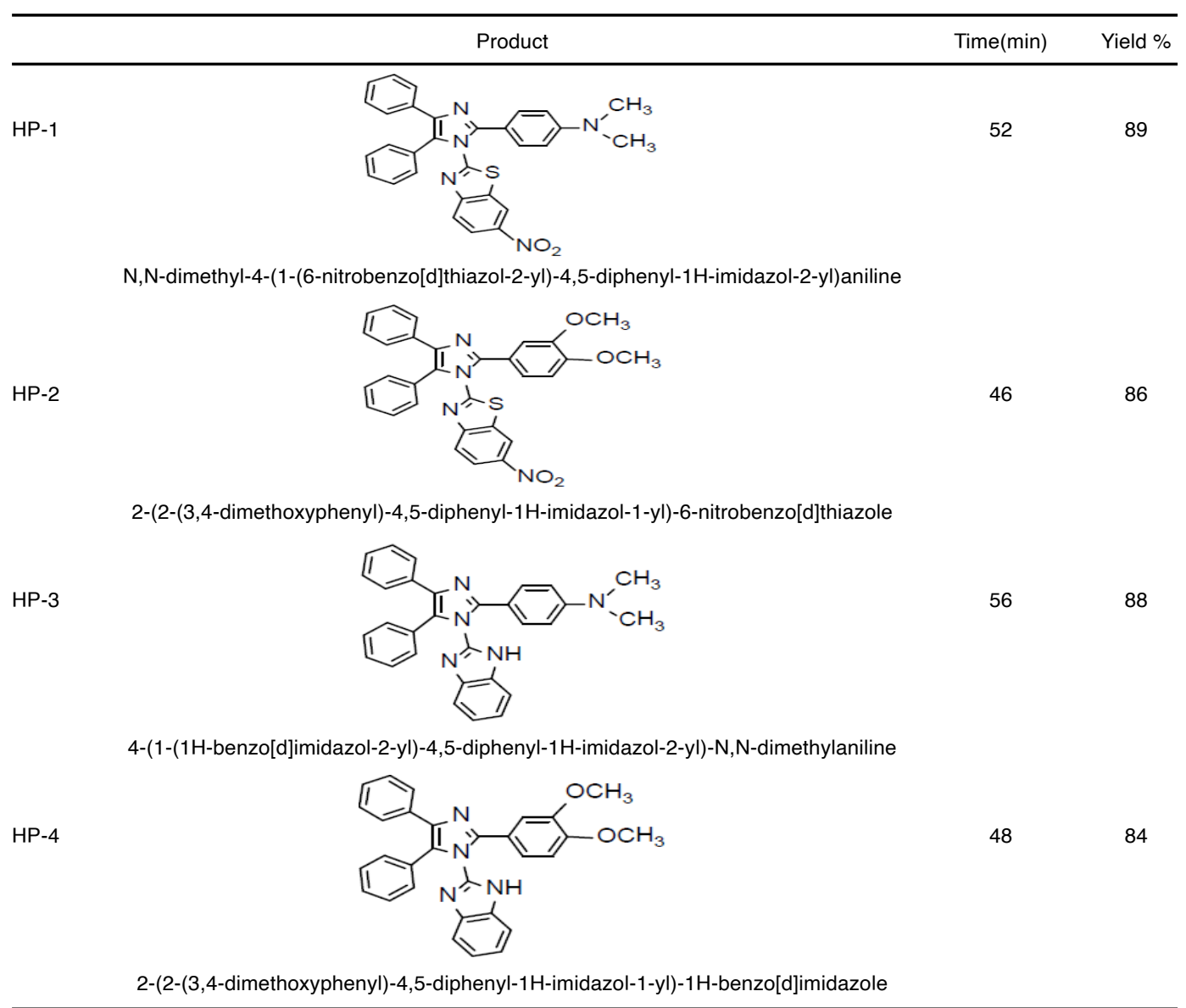

The quantity of catalyst which results in highest efficiency is tested by carrying out a sequence of reactions with similar reaction conditions but varied amount of the catalyst starting from $10 \mathrm{mg}$. We have found that yield of the product significantly enhanced from 62 to $89 \%$ when we increased the amount of catalyst from 10 to 50 $\mathrm{mg}$. The product yield does not change by further increase in the amount of catalyst. So for the further synthesis the amount of catalyst is fixed to $50 \mathrm{mg}$. 
Table 2: Showing efficiency of the brick derived clay catalyst at different amount.

\begin{tabular}{ccc}
\hline Weight of catalyst $(\mathrm{mg})$ & Reaction time $(\mathrm{min})$ & Yield (\%) \\
\hline 10 & 45 & 62 \\
20 & 45 & 74 \\
30 & 45 & 81 \\
40 & 45 & 85 \\
50 & 45 & 89 \\
\hline
\end{tabular}

Reaction conditions; Substrate: Benzil, Aldehydes, Amines and Ammonium acetate, reaction temperature: $70^{\circ} \mathrm{C}$, solvent: ethanol

The recovered catalyst is recycled with ethanol and ready for reuse in the next reaction run. The reused catalyst showed excellent efficiency without any appreciable loss in it. The efficiency of brick derived clay catalyst after successive reaction runs tabulated in Table 3.

Table 3: Showing Efficiency of brick derived clay catalyst after successive reaction runs

\begin{tabular}{cc}
\hline Reaction Runs & $\%$ Yield \\
\hline $1^{\text {st }}$ & 89 \\
$2^{\text {nd }}$ & 88 \\
$3^{\text {rd }}$ & 85 \\
$4^{\text {th }}$ & 84 \\
$5^{\text {th }}$ & 82 \\
\hline
\end{tabular}

We have compared the efficiency of the brick derived clay catalyst with other reported catalysts that are predominantly used in the synthesis of imidazole derivatives like Zeolite, DABCO, $\mathrm{HNO}_{3} @$ nano-SiO ${ }_{2}$ and data tabulated in Table 4.
Table 4: Showing comparison of the brick derived clay catalyst with other reported catalysts for imidazole derivatives synthesis

\begin{tabular}{|c|c|c|c|}
\hline Catalysts & $\begin{array}{c}\text { Solvent- } \\
\text { Temperature }\end{array}$ & $\begin{array}{l}\text { Reaction } \\
\text { Time }\end{array}$ & $\begin{array}{l}\text { Product } \\
\text { Yield\% }\end{array}$ \\
\hline Zeolite $^{32}$ & Ethanol $100^{\circ} \mathrm{C}$ & $85 \mathrm{~min}$ & 87 \\
\hline $\mathrm{DABCO}^{34}$ & $\mathrm{t}-\mathrm{BuOH} 70^{\circ} \mathrm{C}$ & $13-14 \mathrm{~h}$ & 81 \\
\hline $\mathrm{HNO}_{3} @$ nano-SiO ${ }_{2}^{35}$ & solvent-free $100^{\circ} \mathrm{C}$ & $3.5 \mathrm{~h}$ & 90 \\
\hline Brick derived clay & Ethanol $70^{\circ} \mathrm{C}$ & $45-60 \mathrm{~min}$ & 89 \\
\hline
\end{tabular}

This work is primarily focused to enhance the greenness in the synthesis of imidazole derivatives. We have reported novel benzothiazole/benzimidazole tethered imidazole derivatives synthesized by utilizing brick derived clay catalyst. This catalyst is very economical and environmentally benign.

\section{CONCLUSION}

The brick derived clay used in this work qualifies itself on both the fronts, economically as well as environmentally. The yield of products clearly highlights the effectiveness of this catalyst for the synthesis of benzothiazole/benzimidazole tethered imidazole derivatives. This catalyst proves its efficiency by minimizing both the reaction time and waste material. It has delivered excellent yield of the product, moreover this catalyst shows reusability as an important edge over others. Therefore, the brick derived clay can act as a promising candidate for synthesis of benzothiazole / benzimidazole tethered imidazole derivatives with minimal impact on the environment.

\section{ACKNOWLEDGMENT}

We are highly grateful to the Department of Chemistry, DHSGU and SIC, DHSGU for valuable support in this research work.

\section{REFERENCES}

1. Li, B.; Tayebee, R.; Esmaeili, E.; Namaghi, MS.; Maleki, B. RSC Advances., 2020, 10, 40725-40738.

2. Chen, R.; Jalili, Z.; Tayebee, R. RSC Advances., 2021, 11, 16359-16375.

3. Hashemzadeh, A.; Amini, M.M.; Tayebee, R.; Sadeghian, A.; Durndell, L.J.; Isaacs, M.A.; Osatiashtiani, A.; Parlett, C.M.; Lee, A.F. Molecular Catalysis., 2017, 440, 96-106.

4. Erfaninia, N.; Tayebee, R.; Dusek, M.; Amini, M.M. Applied Organometallic Chemistry., 2018, 32(5), 4307.

5. Ghohe, N.M.; Tayebee, R.; Amini, M.M. Materials Chemistry and Physics., 2019, 223,
268-276.

6. Ghohe, N.M.; Tayebee, R.; Amini, M.M.; Osatiashtiani, A.; Isaacs, M.A.; Lee, A.F. Tetrahedron., 2017, 73(40), 5862-5871.

7. Freire, C.; Pereira, C.; Rebelo, S. Catalysis., 2012, 24, 116-203.

8. Vedrine, J. C. Catalysts., 2017, 7, 341.

9. Climent, M. J.; Corma, A.; Iborra, S. RSCAdv., 2012, 2, 16-58.

10. Bhaskaruni, S. V. H. S.; Maddila, S.; Gangu, K.K.; Jonnalagadda, S. B. Arab. J. Chem., 2017, 13, 1142-1178.

11. Takagaki, A.; Sugisawa, M.; Lu, D.; Kondo, J.N.; Hara, M.; Domen, K.; Hayashi, S. JAm Chem Soc., 2003, 125, 5479-5485. 
12. Rownaghi, A.A.; Rezaei, F.; Hedlund, J. Catal Commun., 2011, 14, 37-41.

13. Rahimi, N.; Karimzadeh, R. Appl. Catal. A., 2011, 398, 1-17.

14. Zawrah, M.F.; Gado, R.A.; Feltin, N.; Ducourtieux, S.; Devoille, L. Process Saf Environ., 2016, 103, 237-251.

15. Fort, J.; Vejmelkova, E.; Konakova, D.; Alblova, N.; Cachova, M.; Keppert, M.; Rovnanikova, P.; Cerny, R. J Clean Prod., 2018, 194, 714-725.

16. Madduluri, V.R.; Katari, N.K.; Peddinti, N.; Velpula, V.K.; Burri, D.R.; Kamaraju, S.R.R.; Jonnalagadda, S.B. Res Chem Intermed., 2018, 44, 7619-7639.

17. Madduluria, V.R.; Neelia, C.K.P.; Katari, N.K.; Ganjalaa, V.S.P.; Thirupataiaha, K.; Kamaraju, S.R.R. Catal Commun., 2018, 110, 38-41.

18. Raizada, P.; Singh, P.; Kumar, A.; Pare, B.; Jonnalagadda, S.B. Sep Purif Technol., 2014, 133, 429-437.

19. Raizada, P.; Singh, P.; Kumar, A.; Sharma, G.; Pare, B.; Jonnalagadda,; S.B.; Thakur, P. Appl Catal A: General., 2014, 486, 159-169.

20. Jiang, B.; Rajale, T.; Wever, W.; Tu, S.J.; Li, G.G. Chem Asian J., 2010, 5, 2318-2335.

21. linuma, Y.; Kozawa, S.; Ishiyama, H.; Tsuda, M.; Fukushi, E.; Kawabata, J.; Fromont, J.; Kobayashi, J.; Gesashidine, A. J Nat Prod., 2005, 68, 1109-1110.

22. Negi, A.; Alex, J.M.; Amrutkar, S.M.; Baviskar, A.T.; Joshi, G.; Singh, S.; Banerjee, U.C.; Kumar, R. Bioorg Med Chem., 2015, 23, 5654-5661.

23. Schemeth, D.; Kappacher, C.; Rainer, M.; Thalinger, R.; Bonn, G.K. Talanta., 2016, 153 , 177-185.

24. Wen, S.Q.; Jeyakkumar. P.; Avula, S.R.; Zhang, L.; Zhou, C.H. Bioorg Med Chem Lett., 2016, 26, 2768-2773.

25. Vazquez, G.N.; Figueroa, S.H.; Piedra, M.T.; Galicia, J.V.; Leyva, J.C.R,; Soto, S.E.; Rivera, I.L.; Guardarrama, B.A.; Gomez, Y.R.; Molina, R.V.; Barajas, M.I. Bioorg Med Chem., 2010, 18, 3985-3991.

26. Sontakke, V. A.; Kate, A. N.; Ghosh, S.; More, P.; Gonnade, R.; Kumbhar, N. M.; Kumbhar, A. A.; Chopade, B. A.; Shinde, V. S. New J.
Chem., 2015, 39, 4882-4890.

27. Arulmurugan, S.; Kavitha, H.P. Orient. J. Chem., 2020, 36(4), 672-679.

28. Gaba, M.;Mohan, C. Med.Chem., 2015, 5(2), 58-63.

29. Ajani, O.O.; Aderohunmu, D.V.; Olorunshola, S.J.;Ikpo, C.O.; Olanrewaju, I.O. Orient. J. Chem., 2016, 32(1), 109-120.

30. Zhao, S.; Zhao, L.; Zhang, X.; Liu, C.; Hao, C.; Xie, H.; Sun, B.; Zhao, D.; Cheng, M. Eur. J. Med. Chem., 2016, 123, 514-522.

31. Sadhasivam, G.; Kulanthai, K.; Natarajan, A. Orient. J. Chem., 2015, 31(2), 819-826.

32. Teimouri, A.; Chermahini, A.N. J. Mol. Catal A, 2011, 346, 39-45.

33. Das, B.; Kashanna, J.; Kumar, R.A.; Jangili, P. Monatsh Chem., 2013, 144, 223-226.

34. Murthy, S.N.; Madhav, B.; Nageswar, Y.V.D., Tetrahedron Lett., 2010, 51, 5252-5257.

35. Nikoofar, K.; Dizgarani, S.M. J Saudi Chem Soc., 2017, 21, 787-794.

36. Samai, S.; Nandi, G.C.; Singh, P.; Singh, M.S.; Tetrahedron., 2009, 65, 10155-10161.

37. Kantevari, S.; Vuppalapati, S.V.N.; Biradar, D.O.; Nagarapu, L.; J. Mol. Catal. A: Chem., 2007, 266, 109-113.

38. Wang, X.C.; Gong, H.P.; Quan, Z.J.; Li, L.; Ye, H.L.; Chinese Chem. Lett., 2009, 20, 44-47.

39. Safari, J.; Ravandi, S.G.; Akbari, Z. J. Adv. Res., 2013, 4, 509-514.

40. Mirjalili, B.F.; Bamoniri, A.H.; Zamani, L. Sci. Iran., 2012, 19, 565-568.

41. Alikarami, M.; Amozad, M. Bull Chem Soc Ethiop., 2017, 31, 177.

42. Hashmi, S.Z.; Kishore, D. ARKIVOC., 2016 , 318.

43. Hashmi, S.Z.; Kishore, D.J.; Heterocyclic Chem., 2017, 54, 2912.

44. Borhade, A. V.; Tope, D. R.; Gite S.G. Arabian J Chem., 2017, 10, S559.

45. Bansal, R.; Soni, P.K.; Halve, A.K. J. Heterocyclic Chem., 2018, 55, 1308-1312.

46. Thwin, M.; Mahmoudi, B.; Ivaschukc, O.A.; Yousif, Q.A. RSC Adv., 2019, 9, 15966.

47. Arora, G.; Gupta, R.; Yadav, P.; Dixit, R.; Srivastava, A.; Sharma, R.K. Current Research in Green and Sustainable Chemistry., 2021, 4, 100050. 